\title{
Affinity-based screening of MDM2/MDMX-p53 interaction inhibitors by chemical array: Identification of novel peptidic inhibitors.
}

\section{$\operatorname{AUTHOR}(\mathrm{S}):$}

Noguchi, Taro; Oishi, Shinya; Honda, Kaori; Kondoh, Yasumitsu; Saito, Tamio; Kubo, Tatsuhiko; Kaneda, Masato; Ohno, Hiroaki; Osada, Hiroyuki; Fujii, Nobutaka

\section{CITATION:}

Noguchi, Taro ...[et al]. Affinity-based screening of MDM2/MDMX-p53 interaction inhibitors by chemical array: Identification of novel peptidic inhibitors.. Bioorganic \& medicinal chemistry letters 2013, 23(13): 3802-3805

\section{ISSUE DATE:}

2013-07-01

URL:

http://hdl.handle.net/2433/176375

\section{RIGHT:}

(C) 2013 Elsevier Ltd.; This is not the published version. Please cite only the published version.; この論文は出版社版でありません。引用の際に は出版社版をご確認ご利用ください。 


\section{Affinity-based screening of MDM2/MDMX-p53 interaction inhibitors by chemical array: identification of novel peptidic inhibitors}

Taro Noguchi ${ }^{\mathrm{a}}$, Shinya Oishi ${ }^{\mathrm{a}, *}$, Kaori Honda ${ }^{\mathrm{b}}$, Yasumitsu Kondoh ${ }^{\mathrm{b}}$, Tamio Saito ${ }^{\mathrm{b}}$, Tatsuhiko Kubo ${ }^{\mathrm{a}}$, Masato Kaneda ${ }^{\mathrm{a}}$, Hiroaki Ohno ${ }^{\mathrm{a}}$, Hiroyuki Osada ${ }^{\mathrm{b}}$, Nobutaka Fujii ${ }^{\mathrm{a}, *}$

${ }^{a}$ Graduate School of Pharmaceutical Sciences, Kyoto University, Japan

${ }^{\mathrm{b}}$ Chemical Biology Core Facility, Chemical Biology Department, RIKEN Advanced Science Institute, 2-1 Hirosawa, Wako, Saitama 351-0198, Japan

* Corresponding Authors:

Shinya Oishi, Ph. D., Nobutaka Fujii, Ph. D.

Graduate School of Pharmaceutical Sciences

Kyoto University

Sakyo-ku, Kyoto, 606-8501, Japan

Tel: +81-75-753-4551; Fax: +81-75-753-4570

E-mail (S.O.): soishi@pharm.kyoto-u.ac.jp; E-mail (N.F.): nfujii@pharm.kyoto-u.ac.jp

Abbreviations: FAM, carboxyfluorescein; FP, fluorescence polarization; HBTU, $O$-(1H-benzotriazol-1-yl)- $N, N, N^{\prime}, N^{\prime}$-tetramethyluronium hexafluorophosphate, $\quad$ HOBt, 1-hydroxy-1H-benzotriazole; MDM2, mouse double minute 2 homolog; MDMX, mouse double minute $\mathrm{X}$ homolog; TAMRA, tetramethylrhodamine; TCEP, tris(2-carboxyethyl)phosphine. 


\begin{abstract}
MDM2 and MDMX are oncoproteins that negatively regulate the activity and stability of the tumor suppressor protein p53. The inhibitors of protein-protein interactions (PPIs) of MDM2-p53 and MDMX-p53 represent potential anticancer agents. In this study, a novel approach for identifying MDM2-p53 and MDMX-p53 PPI inhibitor candidates by affinity-based screening using a chemical array has been established. A number of compounds from an in-house compound library, which were immobilized onto a chemical array, were screened for interaction with fluorescence-labeled MDM2 and MDMX proteins. The subsequent fluorescent polarization assay identified several compounds that inhibited MDM2-p53 and MDMX-p53 interactions.
\end{abstract}

Keywords: MDM2, MDMX, p53 protein, HTS, microarray technology 
MDM2 and MDMX are negative regulators of the tumor suppressor protein $\mathrm{p} 53$, and therefore confer tumor development and survival. ${ }^{1,2}$ MDM2 and MDMX bind to the N-terminal transactivation domain of p53 with high affinity to inhibit functions associated with regulating responsive gene expression. ${ }^{3-6}$ MDM2 has E3 ubiquitin ligase activity and thus also regulates the stability of p53 by proteasomal degradation, thereby conferring effective down-regulation of cellular p53 protein levels. ${ }^{7-10}$ MDMX has no ubiquitin ligase activity, yet forms an MDMX-MDM2 heterodimer via interaction between their C-terminal RING finger domains. This heterodimer stimulates MDM2-mediated ubiquitination of the p53 and subsequent degradation. ${ }^{11-14}$ As such, high expression of MDM2 and MDMX results in a reduction in the activity and expression level of the p53 in cancer cells. ${ }^{15}$

Inhibitory compounds that block the interaction between MDM2-p53 and MDMX-p53 have been identified $^{16}$ using various types of high throughput screening technologies. ${ }^{17}$ For example, MDM2-p53 interaction inhibitors, nutlin-1, -2, and -3, were identified by surface plasmon resonance (SPR) analysis. ${ }^{18}$ SJ-172550 is an MDMX-p53 interaction inhibitor, which was identified by a fluorescence polarization (FP) assay. ${ }^{19}$ These facile technologies are based on the evaluation of inhibitory effects by compounds against p53 binding to MDM2/MDMX.

Affinity-based screening is an alternative approach for the identification of potential inhibitors against protein-protein interactions (PPIs). ${ }^{20}$ This approach explores PPI inhibitors against previously recognized binding pockets as well as search for potential binding molecules that interact with alternative or unexpected pockets present in the target proteins. The phage display method is an example of an affinity-based screening technique, which has been employed to identify peptide-based MDM2 binding peptides. ${ }^{21}$ The microarray technology has also been used for the affinity-based screening of peptides and small-molecules, in which the potential hit compounds with affinity to the loaded protein can be selected based on fluorescent signals using a microarray scanner. ${ }^{22}$ We have previously established chemical array screening as a novel method of small 
molecule microarrays. On the chemical array, small molecules are immobilized at a variety of positions to a carbene-based photo-cross linker. ${ }^{23}$ Using this photo-crosslinked chemical array technology, there have been some examples that have identified bioactive compounds such as carbonic anhydrase II inhibitors and a pirin-Bcl3 inhibitor, Tph A. ${ }^{24,25}$ In this study, we report a novel approach for the identification of peptidic inhibitors against MDM2-p53 and MDMX-p53 interactions.

There have been two reports on the synthesis of MDM2 and MDMX proteins by combining Boc-based solid-phase peptide synthesis (SPPS) with native chemical ligation. ${ }^{21,26}$ Although this approach would be applicable to large-sized protein synthesis, a more facile stepwise Fmoc-SPPS approach was undertaken for these proteins in this study (Scheme 1). The p53-binding domain of MDM2 and MDMX (designated MDM2 $2^{25-109}$ and $\mathrm{MDMX}^{24-108}$, respectively) were synthesized by standard Fmoc-SPPS on a H-Rink Amide-ChemMatrix resin using HBTU/HOBt/(i-Pr) $)_{2} \mathrm{NEt}$ activation. After chain assembly, deprotection of the side chain protecting groups and cleavage from the resin with the cocktail [TFA/thioanisole/m-cresol/1,2-ethanedithiol/ $\mathrm{H}_{2} \mathrm{O}$ (80:5:5:5:5)], followed by RP-HPLC purification afforded the expected peptides. For the preparation of fluorescent MDM2 and MDMX proteins bearing a single tetramethylrhodamine moiety (TAMRA) (designated $\mathrm{MDM}^{\mathrm{TMR}}$ and MDMX ${ }^{\mathrm{TMR}}$, respectively), 5-hexynoic acid was conjugated via a diglycine linker on the peptide resin. After purification of $\mathrm{MDM}^{25-109}$ and $\mathrm{MDMX}^{24-108}$ with an N-terminal alkyne tag, treatment with TAMRA-azide in the presence of $\mathrm{Cu}(\mathrm{I})$ provided fluorescent $\mathrm{MDM} 2^{\mathrm{TMR}}$ and $\mathrm{MDMX}^{\mathrm{TMR}}$, respectively. The synthetic MDM2 and MDMX proteins and the fluorescent derivatives, $\mathrm{MDM}^{\mathrm{TMR}}$ and MDMX ${ }^{\mathrm{TMR}}$, were refolded in PBS buffer $(\mathrm{pH}=7.4)$ containing $0.5 \mathrm{mM}$ TCEP, 60 $\mathrm{mM}$ guanidine and $0.005 \%$ Tween-20.

To validate the structures of the synthetic proteins, we evaluated circular dichroism (CD) spectra of MDM2 25-109 and MDMX ${ }^{24-108}$ (Figure 1). Negative bands at $208 \mathrm{~nm}$ and $222 \mathrm{~nm}$ indicated the presence of $\alpha$-helix secondary structure elements, which is characteristic for MDM2 and MDMX, 
and supported by previous crystal structure and CD analyses. ${ }^{21,27}$ To further verify the biological activity of the synthetic proteins, binding affinities of MDM2 and MDMX towards the p53 peptide sequence were evaluated by SPR analysis. Varying concentrations of MDM2 and MDMX proteins were analyzed by a NeutrAvidin-coated NLC sensor chip (BioRad) on which the biotinylated wild-type p53 peptide $^{19}$ (biotinyl-aminocaproyl-GSGSSQETFSDLWKLLPEN-NH2) was immobilized (Figure 2). MDM2 $2^{25-109}$ and $\mathrm{MDMX}^{24-108}$ bound the p53 peptide with $K_{\mathrm{d}}$ values of 0.803 and $2.22 \mu \mathrm{M}$, respectively, which supported the correct folding of these proteins. ${ }^{19}$ The binding affinities (Kd values) of MDM2 $2^{\mathrm{TMR}}$ and MDMX ${ }^{\mathrm{TMR}}$ towards the $\mathrm{p} 53$ peptide were 0.616 and $2.14 \mu \mathrm{M}$, respectively, indicating that $\mathrm{N}$-terminal modification of synthetic MDM2 and MDMX had no effect on the folding of these proteins or the biological functions. ${ }^{17}$

With these synthetic proteins in hand, we assessed the binding ability of MDM2 ${ }^{\mathrm{TMR}}$ and $\mathrm{MDMX}^{\mathrm{TMR}}$ to the p53 peptide (designated L-p53: H-LTFEHYWAQLTS-NH ${ }_{2}$ ) immobilized on a microarray via carbene-mediated covalent bond(s). The enantiomer peptide (designated D-p53) was used as a negative control. MDM2 $2^{\mathrm{TMR}}$ and $\mathrm{MDMX}^{\mathrm{TMR}}$ bound to L-p53 in a highly selective manner (Figure 3). Higher MDM2-p53 binding compared with the MDMX-p53 interaction was observed, which is consistent with the more potent binding affinity of MDM2 to the p53 peptide in the SPR analysis.

To identify the inhibitor candidates for MDM2-p53 and MDMX-p53 interactions, we next carried out microarray screening using the MDM2 $2^{\mathrm{TMR}}$ and MDMX ${ }^{\mathrm{TMR}}$ constructs. Fifty-four hit compounds were identified from the 7,600 compounds of the in-house chemical library that were immobilized on the microarray using $5 \mathrm{mM}$ solutions. Of these, 6 molecules and 10 molecules showed selective binding to MDM2 and MDMX, respectively. The other 38 molecules exhibited binding to both MDM2 and MDMX.

To select small molecules that bind to the p53 binding pocket(s) in MDM2 and MDMX in this study, the inhibitory effects on MDM2-p53 and MDMX-p53 interactions were further evaluated for 
the 54 hit compounds by an FP assay using a fluorescein-labeled p53 peptide $\left(\right.$ FAM-LTFEHYWAQLTS-NH2). ${ }^{28}$ Three dual inhibitors against both interactions were obtained (Figure 4): KPYA52218 (1), KPYB00497 (2) and KPYB00556 (3) $\left[\mathrm{IC}_{50}(\mathbf{1})=8.51 \mu \mathrm{M}\right.$ for MDM2, $32.4 \mu \mathrm{M}$ for MDMX; $\operatorname{IC}_{50}(2)=22.2 \mu \mathrm{M}$ for MDM2, $42.1 \mu \mathrm{M}$ for $\operatorname{MDMX} ; \operatorname{IC}_{50}(3)=21.3 \mu \mathrm{M}$ for MDM2, 52.5 $\mu \mathrm{M}$ for MDMX]. In the initial microarray analysis, these molecules 1-3 were also identified to show dual binding to MDM2 and MDMX. Although MDM2 and MDMX share homologous sequences in their p53-binding domains, many of the known MDM2-p53 PPI inhibitors do not effectively interact with MDMX-p53 probably because of the shallower and wider p53-binding pocket in MDMX. ${ }^{29}$ These dual inhibitors represent promising anti-cancer agent leads against cancer cells in which MDM2 and/or MDMX are overexpressed..$^{30}$ To gain insight into the effect on cell proliferation, growth inhibition by compounds 1-3 against human lung carcinoma-derived A549 cells was assessed. Compounds $\mathbf{1}$ and $\mathbf{3}$ showed no effect on cell growth at $30 \mu \mathrm{M}$, whereas cell growth was inhibited by compound $2\left(\mathrm{EC}_{50}=13.7 \mu \mathrm{M}\right)$.

Of note, in the screening process in this study, the biological data from FP assays did not necessarily correspond to the binding ability obtained in the initial microarray screening, possibly owing to structural modification of the molecules bound to the microarray and potential binding to other binding site(s) than the p53 binging pocket. However, the microarray technology successively facilitated the selection process and the identification of potential inhibitors.

In conclusion, we have established screening protocols for binding molecules of MDM2 and MDMX by chemical array technology using synthetic fluorescent proteins. The preliminary screening of an in-house chemical library identified a number of binding molecules towards MDM2 and MDMX. The subsequent FP assay identified three dual inhibitors of MDM2-p53 and MDMX-p53 interactions. This new strategy should facilitate the identification process of MDM2-p53 and MDMX-p53 PPI inhibitors, and further screening of a number of small-molecules is now in progress. 


\section{Acknowledgments}

This work was supported by Grants-in-Aid for Scientific Research; Targeted Protein Research Program; and Platform for Drug Discovery, Informatics, and Structural Life Science from MEXT, Japan.

\section{Supplementary data}

Supplementary data associated with this article can be found, in the online version, at \#\#\#\#\#\#\#. 


\section{References}

1. Toledo, F.; Wahl, G. M. Nat. Rev. Cancer 2006, 6, 909.

2. Wade, M.; Wang, Y. V.; Wahl, G. M. Trends Cell Biol. 2010, 11, 694.

3. Gahilly-Snyder, L.; Yang-Feng, T.; Francke, U.; George, D. L. S. Cell Mol. Genet. 1987, 13, 235.

4. Momand, J.; Zambetti, G. P.; Olson, D. C.; George, D.; Levine, A. J. Cell 1992, 69, 1237.

5. Shvarts, A.; Steegenga, W. T.; Riteco. N.; van Laar, T.; Dekker, P.; Bazuine, M.; van Ham, R. C.; van der Houven van O. W.; Hateboer, G.; van der Eb, A. J.; Jochemsen, A. G. EMBO J. 1996, 15, 5349.

6. Oliner, J. D.; Pietenpol, J. A.; Thiagalingam, S.; Gyuris, J.; Kinzler, K. W.; Vogelstein, B. Nature1993, 362, 857.

7. Haupt, Y.; Maya, R.; Kazaz, A.; Oren, M. Nature 1997, 387, 296.

8. Stommel, J. M.; Wahl, G. M. Cell Cycle 2005, 4, 411.

9. Honda, R.; Tanaka, H.; Yasuda, H. FEBS Lett. 1997, 22, 25.

10. Micheal, D.; Oren, M. Semin. Cancer Biol. 2003, 13, 49.

11. Sharp, D. A.; Kratowicz, A. K.; Sank, M. J.; George, L. J. Biol. Chem. 1999, 274, 38189.

12. Marine, J. C. W.; Dyer, M. A.; Jochemsen, A. G. J. Cell Sci. 2007, 120, 371.

13. Wang, X.; Wang, J.; Jiang, X. J. Biol. Chem. 2011, 286, 23725.

14. Wang, X. Cell Cycle 2010, 10, 4225.

15. Teledo, F.; Wahl, G. M. Int. J. Biochem. Cell Biol. 2007, 39, 1476.

16. Wade, M.; Li ,Y. C.; Wahl G. M. Nat. Rev. Cancer 2013, 13, 83.

17. Tsuganezawa, K.; Nakagawa, Y.; Kato, M.; Taruya, S.; Takahashi, F.; Endoh, M.; Utata, R.; Mori, M.; Ogawa, N.; Honma, T.; Yokoyama, S.; Hashizume, Y.; Aoki, M.; Kasai, T.; Kigawa, T.; Kojima, H.; Okabe, T.; Nagano,T.; Tanaka, A. J. Biomol. Screen. 2013, 18, 191.

18. Vassilev, L. T.; Vu, B. T.; Graves, B.; Carvajal, D.; Podlaski, F.; Filipovic, Z.; Kong, N.; Kammlott, U.; Lukacs, C.; Klein, C.; Fotouhi, N.; Liu, E, A. Science 2004, 303, 844. 
19. Reed, D.; Shen, Y.; Shelat, A. A.; Arnold, L. A.; Ferreira, A. M.; Zhu, F.; Mills, N.; Smithson, D. C.; Regni, C. A.; Bashfoldm D.; Cicero, S. A.; Schulman, B. A.; Jochemsen, A. G.; Guy, R. K.; Dyer, M. A. J. Biol. Chem. 2010, 2, 10786.

20. Oishi, S.; Watanebe, K.; Ito, S.; Tanaka, M.; Nishikawa, H.; Ohno, H.; Shimane, K.; Izumi, K.; Sakagami, Y.; Kodama, E, N.; Matsuoka, M.; Asai, A.; Fujii, N. Med. Chem. Commun. 2010, 1, 276.

21. Pazgier, M.; Liu, M.; Zou, G.; Yuan, W.; Li, C.; Li, C.; Li, J.; Monbo, J.; Zella, D.; Tarasov, S. G.; Lu, W. Proc. Natl. Acad. Sci. U.S.A. 2009, 106, 4665.

22. Foong, Y. M.; Fu, J.; Yao, S. Q.; Uttamchandani, M. Curr. Opin. Chem. Biol. 2012, 16, 234.

23. Kanoh, N.; Kumashiro, S.; Simizu, S.; Kondoh, Y.; Hatakeyama, S.; Tashiro, H.; Osada, H. Angew. Chem., Int. Ed. 2003, 42, 5584.

24. Miyazaki, I.; Simizu, S.; Ichimiya, H.; Kawatani, M.; Osada, H. Biosci., Biotechnol., Biochem. 2008, 72, 2739.

25. Miyazaki, I.; Simizu, S.; Okumura, H.; Takagi, S.; Osada, H. Nat. Chem. Biol. 2010, 6, 667.

26. Zhan, C.; Varney, K.; Yuan, W.; Zhao, L.; Lu, W. J. Am. Chem. Soc. 2012, 134, 6855.

27. Liu, M.; Pazgier, M.; Li, C.; Yuan, W.; Li, C.; Lu, W. Angew. Chem. Int. Ed. 2010, 49, 3649.

28. Czarna, A.; Popowicz, G. M.; Pecak, A.; Wolf, S.; Dubin, G.; Holak, T. A. Cell Cycle 2009, 8, 1176.

29. Joseph, T. L.; Madhumalar, A.; Brown, C. J.; Lane, D. P.; Verma, C. Cell Cycle 2010, 9, 1167.

30. Danovi, D.; Meulmeester, E.; Pasini, D.; Migliorini, D.; Capra, M.; Frenk, R.; Graaf, P.; Francoz, S.; Gasparini, P.; Gobbi, A.; Helin, K.; Pelicci, P. G.; Jochemsen, A. G.; Marine, J. C. Mol. Cell. Biol. 2004, 24, 5835. 
Scheme 1. Synthesis of MDM2 and MDMX proteins.

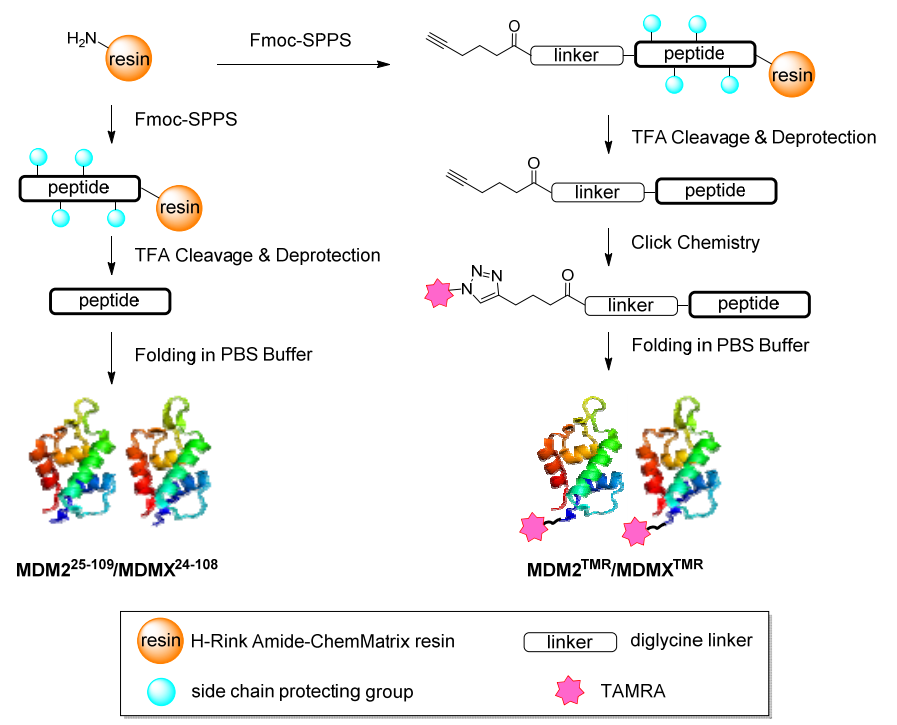


Figure 1. CD spectra of MDM2 and MDMX proteins.

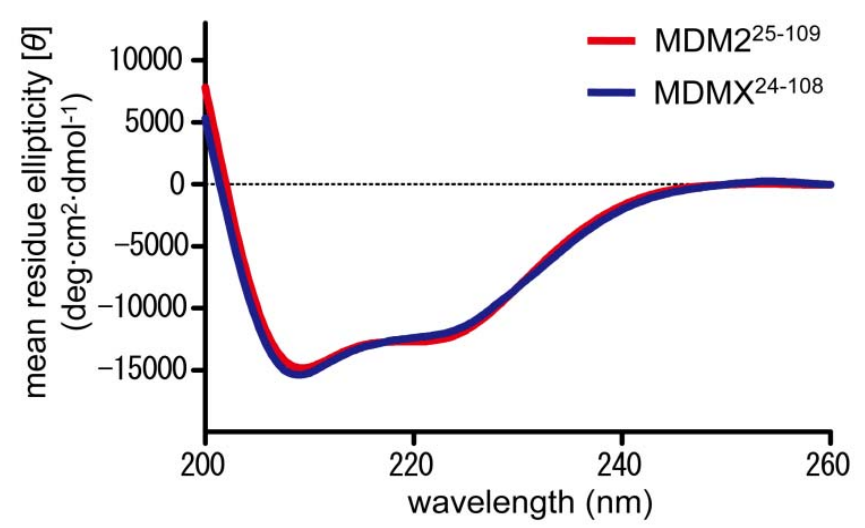

CD spectra of $\mathrm{MDM}^{25-109}$ and $\mathrm{MDMX}^{24-108}(4 \mu \mathrm{M})$ were measured at room temperature in PBS containing 0.1 mM TCEP (pH 7.4). 
Figure 2. Surface plasmon resonance analysis of MDM2 and MDMX proteins for binding to a p53 peptide.
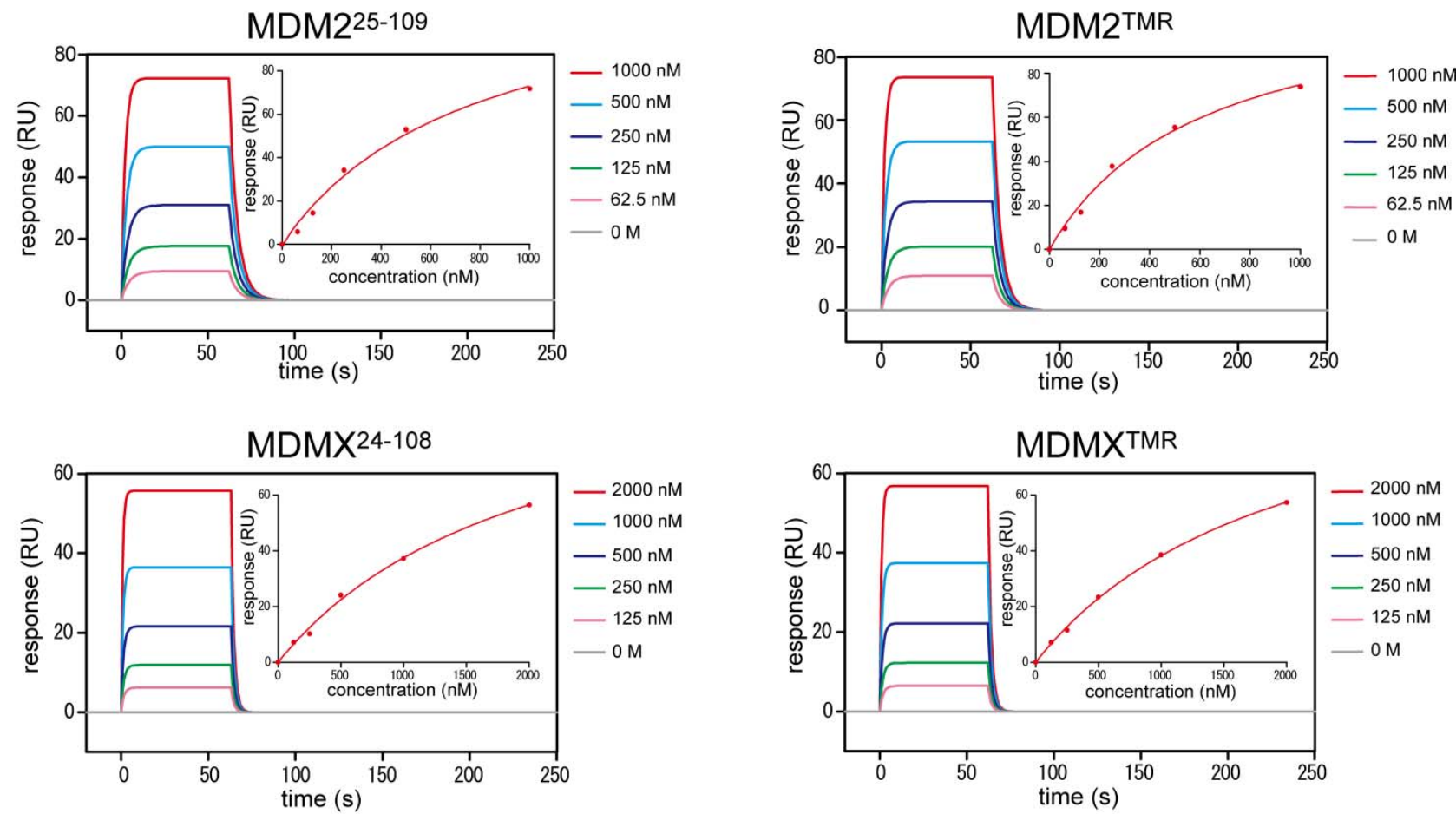

Binding kinetics were evaluated using a biotinylated wild-type p53 peptide immobilized on a NLC sensor chip (43 RUs) at $20{ }^{\circ} \mathrm{C}$. PBS (pH 7.4) containing $0.005 \%$ Tween-20 was used as the running buffer. 
Figure 3. Microarray analysis of $\mathrm{p} 53$ peptides using MDM2 $2^{\mathrm{TMR}}$ and $\mathrm{MDMX} \mathrm{TMR}^{\mathrm{TM}}$ proteins.

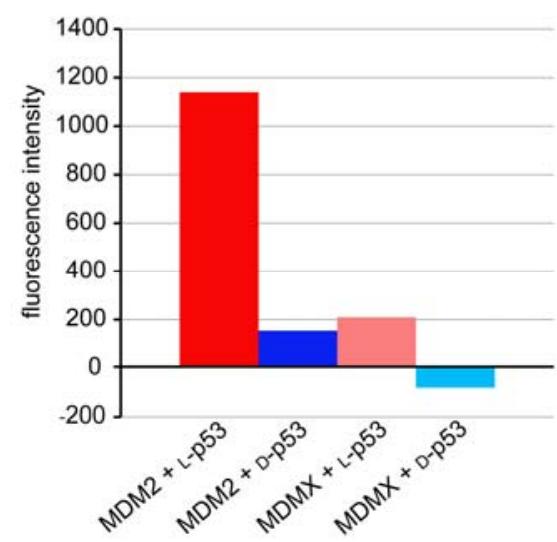

$\mathrm{MDM}^{\mathrm{TMR}}$ and $\mathrm{MDMX}^{\mathrm{TMR}}$ binding $(1 \mu \mathrm{M}$ in $1 \%$ skim-milk-TBS-T) was assessed using a microarray, on which L-p53 (H-LTFEHYWAQLTS-NH2) or D-p53 was immobilized at the concentration of $6.6 \mathrm{mM}$. 
Figure 4. Structures and biological activity of the hit compounds<smiles>COc1ccc(COC(=O)NC(C(=O)N[C@@H](CCC(=O)O)C(=O)NC(Cc2cn(S(=O)(=O)c3ccccc3C)n(-c3ccccc3)c2=O)C(=O)NCC(C)C)C(C)C)cc1</smiles>

KPYA52218 (1)

IC 50 (MDM2): $8.51 \mu \mathrm{M}$

IC 50 (MDMX): $32.4 \mu \mathrm{M}$

$\mathrm{EC}_{50}$ (A549 cell): $>30 \mu \mathrm{M}$<smiles>CSSc1ncccc1[N+](=O)[O-]</smiles><smiles>CCC(C)C(NC(=O)[C@H](Cc1ccccc1)NC(=O)[C@H](CSSC)NC(C)(C)C)C(=O)N[C@@H](CCCNC(=N)NS(=O)(=O)c1c(C)cc(C)cc1C)C(C)C</smiles>

IC 50 (MDM2): $22.2 \mu \mathrm{M}$

$\mathrm{IC}_{50}$ (MDMX): $42.1 \mu \mathrm{M}$

$\mathrm{EC}_{50}$ (A549 cell): $13.7 \mu \mathrm{M}$

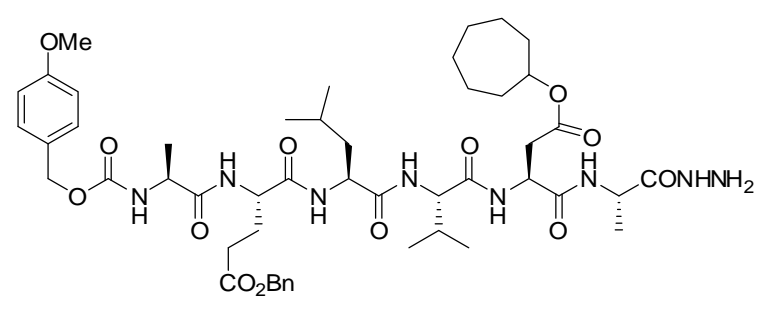

KPYB00556 (3)

$\mathrm{IC}_{50}$ (MDM2): $21.3 \mu \mathrm{M}$

IC 50 (MDMX): $52.5 \mu \mathrm{M}$

$\mathrm{EC}_{50}$ (A549 cell): $>30 \mu \mathrm{M}$

IC50 for MDM2 and MDMX were measured by a fluorescent polarization assay using a fluorescein-labeled p53 peptide $(0.5 \mathrm{nM})$ and $\mathrm{MDM}^{25-109}(10 \mathrm{nM})$ or $\mathrm{MDMX}^{24-108}(50 \mathrm{nM})$. The EC50 values were measured by a cell growth inhibition assay using A549 cells. Compounds 1 and 3 were insoluble at $>30 \mu \mathrm{M}$ in the medium for growth inhibition assay. 